\title{
Remarks on Swedenborgian Elements in the Literary Production of Johan Ludvig Runeberg
}

\author{
TIINA MAHLAMÄKI \& TOMAS MANSIKKA \\ University of Turku / Åbo Akademi University
}

\begin{abstract}
This article sets out to trace possible influences of Emanuel Swedenborg, the Swedish theosophist and spirit-seer, in the production of the Finnish national poet Johan Ludvig Runeberg. We argue that the influence of Swedenborgianism on nineteenth-century culture in Finland was greater than has generally been suggested by literary scholars. The first part of the article provides a historical background of Swedenborgianism in the country. The latter part indicates a larger epistemic and religious accord between Swedenborg and Runeberg, to be accounted for in greater detail in terms of influence. Both authors subscribed to an emblematic worldview within the Classical discourse of nature as a book, ultimately supported by a framework of logocentrism and theism. Runeberg's discussion of words and things, and his use of the metaphor of light, places him within a mainstream nineteenth-century spirituality, which may be juxtaposed, in addition to general Romantic views, also with Swedenborgian sources.
\end{abstract}

Keywords: Johan Ludvig Runeberg, Emanuel Swedenborg, Johann Georg Hamann, Ralph Waldo Emerson, poetry, book of nature, emblematic word view, words and things, metaphor of light

On the first of May 1859 Johan Ludvig Runeberg wrote a letter to his close friend, the Swedish baron, poet and member of the Swedish Academy Bernhard von Beskow (1796-1868). In this letter Runeberg discussed a work published by von Beskow the previous year; Runeberg had not yet read it, but he was looking forward to receiving a copy. Until Runeberg became paralyzed in 1863, the two gentlemen had been accustomed to exchanging letters once or twice a year. In commenting on the work, a biography of Emanuel Swedenborg (von Beskow 1858), Runeberg was 55 years old and at the peak of his literary career. Somewhat startlingly, Runeberg confesses in the letter to a lifelong interest in Swedenborg's person and spiritual philosophy:

I have always felt a certain attraction to this deep nature, although my knowledge of him has always been incomplete, and I have admired the genius 
which expresses itself in all I've seen of his writings. His teachings of the spirit-world, his visions have captured my thoughts, knowing their source is the most honest, conscientious individual, not figments of the empty desire of an undemanding imagination. ${ }^{1}$

What makes the letter even more intriguing is that it is not only the sole document which explicitly demonstrates Runeberg's familiarity with Swedenborg but is at the same time an eloquent, admirably written argument in favor of his philosophy. In his reply to the letter, von Beskow lamented that Runeberg's portrayal came too late to be included in his book: 'When you have read the book, you will not regard it as flattery if I say that of all judgments of the thinkers quoted therein, no one has in my opinion more clearly expressed the peculiarity of this enigmatic being than you in your letter.' ${ }^{2}$ We return below to Runeberg's letter; at this point we address certain problems facing researchers trying to grasp Swedenborg's impact on nineteenth-century Finnish culture.

The whole issue of Swedenborg's possible influence on Runeberg has so far been glanced at only briefly, as a curiosity. There are, we argue, at least three reasons for this. First, the tracing of Swedenborgian influences has not been part of cultural and literary studies in Finland. Secondly, a scholarly consensus has prevailed that Swedenborg was largely unknown to nineteenth-century writers in Finland, a view that can be seen at least in part as following from the first factor. The third cause is more particularly connected with Runeberg. If the national poet of Finland was, as the letter to von Beskow suggests, fairly well acquainted with the Swedish visionary, and at least for the moment impressed with him, we would expect to find in his vast production other references as well. These, however, do not occur, and the absence of explicit references has been regarded as indicating a lack of interest.

In a recent article, Jane Williams-Hogan sets out to trace Swedenborgian influences on three major nineteenth-century Scandinavian artists: Edvard Munch, Søren Kirkegaard and August Strindberg. She points out

\footnotetext{
1 'Alltid har jag känt en viss dragning till denna djupa natur, så ofullständig än min kännedom om honom varit, och jag har beundrat det snille, som röjt sig i allt hvad jag sett af honom anfördt. Sjelfva hans läror om andeverlden, hans syner hafva fängslat min eftertanke, då jag vetat att de haft sin källa i den ärligaste, samvetsgrannaste personlighet, och icke varit foster af en lättfärdig inbillnings tomma diktlystnad.' (Runeberg 1879, 279.) All translations of Runeberg's texts are by the authors.

2 'När du läst minnet skall du ej anse som smicker, om jag säger, att af alla de tänkares omdömen, som der anförts, har ingen, i mitt tycke, klarare angifvit det egna hos detta hemlighetsfulla wäsen, än du i ditt bref...' (Runeberg 1973, 160).
} 
that 'since Swedenborg's perspective is not part of the "taken for granted" intellectual heritage of Western scholars [...], his contribution to a specific writer, philosopher, or artist can go unnoticed, particularly if the person does not personally mention Swedenborg' (Williams-Hogan 2008, 257). It is well established among scholars that in the course of the nineteenth century Swedenborg's ideas became partly fused and amalgamated with other spiritualist and philosophical approaches, resulting in a specific mode of mainstream spirituality (see e.g. Siukonen 2000). Given also that Swedenborg himself was heir to earlier traditions such as for instance physico-theology and seventeenth-century Neo-Platonism (Lamm 1915, 28, 69-94), there is naturally a risk of over-interpretation as to a Swedenborgian influence on a Platonizing poet such as Runeberg; to put it differently, of making Runeberg more Swedenborgian than he actually was. On the other hand, while certain ideas and conceptions most probably reached Runeberg along mainstream paths, bearing in mind his theological training, we will show that some of the themes and ideas in Runeberg's thinking had a perceptible recurrence among Swedenborgian writers. Leaving the question of sources and influences aside, we approach the subject by examining traits within a shared foundation of ideas peculiar to the era, in which Swedenborgianism held a particular prominence. To this end, we also employ comparisons with other authors, such as Johann Georg Hamann (1730-1788) and Ralph Waldo Emerson (1803-1882), in order to more fully grasp possible Swedenborgian traits in Runeberg. We have, moreover, chosen to restrict our readings of Runeberg mainly to his Letters to an old Gardener and the letter to von Beskow. Thus Runeberg's epic cycles and poems are referred to only sparingly; we are fully aware that a more inclusive examination would require a different and much larger study than this one.

Parallel with this undertaking, a closer assessment of the cultural milieu of nineteenth-century Finland in general might, we believe, convey a different picture of the status of Swedenborg among the educated classes than has hitherto been prevalent. As this is in part presented elsewhere (Mahlamäki 2010; Mahlamäki forthcoming), we here briefly review some of the findings and arguments. An examination of nineteenth-century Finnish newspapers (predominantly published in Swedish) reveals that Swedenborg was by no means forgotten in the course of the century. On the contrary: he was very much of a 'media attraction', frequently discussed in the press. The newspapers contain recurrent advertisements for published translations (into Swedish) of Swedenborg's writings and compilations of his texts, as well as biographies and commentaries on his ideas. He is also mentioned both 
in the news and in columns offering astonishing occurrences, anecdotes and amusing stories. In short stories and serializations Swedenborg's name also occasionally occurs in metaphorical usage, such as 'She is like a female Swedenborg, the only difference being that Swedenborg was wise and she is silly'. The frequent references to Swedenborg as a spirit-seer testify that Swedenborg was not considered to need further portrayal, as readers were expected to be familiar with his character. We are therefore challenging the predominant view of Swedenborg as largely unknown to Finnish writers; rather the opposite, we position him as a popular subject and well-known scholar, recurrently discussed both in the press and by contemporary authors of established reputation, such as P. D. A. Atterbom, Thomas Thorild and Carl Jonas Love Almqvist, all of whom were widely read in Finland.

\section{The Religion of Johan Ludvig Runeberg}

Johan Ludvig Runeberg (1804-1877) was a Swedish-speaking Finn who wrote all of his works in Swedish, a language common in publications of the time. As a young man he studied Latin and Greek at the Academy of Turku (i.e. the university), graduating in 1827. In 1828 he moved to Helsinki, where he became active in the cultural life in the new capital; he was one of the founding members of the Finnish Literature Society. In 1837 he settled down with his family in Porvoo (in Swedish Borgå), a small town near the capital, working as a lecturer and later principal of the Porvoo Gymnasium. Runeberg's poetical works, above all Hanna (published in 1836), brought him recognition in both Finland and Sweden; in 1839, Atterbom conferred upon him the laudatory epithet 'poetic realist'. As the chief author of the new hymnal of the Finnish Lutheran Church, Runeberg was established already during his lifetime as a national hero. (See e.g. Ahokas 1997; Viljanen 1948; 1949; Wrede 2005.)

In his poems Runeberg describes, in Herderian fashion, the beauty of Finnish nature, its rural life and its people. A recurrent theme is the intimate union between the natural world and the human soul, involving a correspondence between natural processes and the inner life of man. His most influential work, The Tales of Ensign Stål (Fänrik Ståls sägner), is a heroic and epic collection of poems portraying Finnish soldiers in the 'Finnish War' of 1808-1809 (a war between Russia and Sweden; part of the Napoleonic Wars), in which Sweden lost its eastern provinces and Finland became a Grand Duchy of the Russian Empire. The first part of the work was published in 1848 and the second in 1860; it had a huge impact in shaping the Finnish 
national identity and in arousing a patriotic spirit. The first of the poems, 'Vårt land' (Our Land), with a melody composed by Friedrich Pacius, became the Finnish national anthem and was sung publicly for the first time in May of 1848 at the student festivities. Moreover, the first stanza of the printed poem was accompanied by an illustration, showing a landscape - a lake with small islands lying behind a forest - which subsequently became emblematic of a truly 'Finnish' national landscape. (Viljanen 1948, 227.)

As the national poet of Finland, Runeberg's life and work have naturally been studied carefully. Runeberg's religiosity has also been the subject of a number of studies (see e.g. Belfrage 1917; Ruin 1936; Laurila 1937; Ringbom 1954; Hansson 2004; Wrede 2005). Many of these studies date back to the first half of the twentieth century, and more recent scholars have devoted less attention to the religious aspect (see Hansson 2004, 70). The early studies share a tendency to emphasize Runeberg as indeed a good Christian, albeit in his own way. Runeberg had a theological education, but did not, contrary to common custom, hold a clerical position. Nor was he an eager church-goer. What has been fairly difficult to explain in relation to Runeberg's religiosity is his approach to nature. In contrast to Lutheran and nineteenth-century pietistic views of nature, which were inclined to stress the natural world from the vantage point of the Fall, Runeberg emphasized a Romantic view of nature: as a place not of alienation or disorder but of venerating and experiencing God. In Runeberg's theistic view, human beings and nature are in diverse ways reliant on each other. Nature is subject to devotion, but is also a great book to be contemplated and examined. In earlier studies this approach has usually been described as mystic, pantheistic or panentheistic. (See Hansson 2004, 70-72; Belfrage 1917; Viljanen 1948; 1949; Wrede 2005.)

Runeberg's theism is voluntaristic; it is not God's Rationality but his Will that manifests itself in nature and history. In Romantic philosophy, poetical discourse was held to be superior to scientific or philosophical language in expressing religious truths. As the leading poet of the Finnish nation Runeberg was confident he had a divine commission, thus conforming to God's will as inherent in the world's order. Runeberg's religion is ultimately emotional and anti-intellectual; it is in a sense similar, as we shall show, to that of Johann Georg Hamann. Faith is the guiding principle by which the mind is enlightened, in a world mysteriously penetrated by the word, or God's voice, in conscience and nature. Prayer and the inner voice of man are the foremost paths to conversation with God. (Wrede 2005, 189-90, 200-1.) 


\section{Scientist and Visionary Emanuel Swedenborg}

Emanuel Swedenborg was a Swedish scientist and visionary who did his life's work at the Swedish Board of Mines, but is remembered and valued above all for his spiritual and religious writings. After decades of working in the natural sciences, in his late 50s (1745) Swedenborg experienced a spiritual crisis during which his 'inner eyes' were opened, granting an ability to perceive the spiritual world. (See e.g. Lamm 1915; Bergquist 2005; Williams-Hogan 2005, 2298-9.) Swedenborg wrote of his gradual spiritual development in Heaven and Hell (1758):

I have frequently been permitted both to perceive and to see that there is a true light that enlightens the mind, and it is quite unlike the light called natural illumination. I have been gradually raised into that light; and as I have been raised my understanding has been enlightened until I could perceive what I had not perceived before, and at length such things as could never be grasped by thought from natural illumination. (Heaven and Hell, §130; translation in Bergquist 2005, 208.)

When Swedenborg set aside his scientific work and immersed himself in the spiritual, this was not a leap in the dark. He was born and raised as the son of Jesper Svedberg (1653-1735): clergyman, Professor of Theology and Bishop of Skara, pious religious thinker, and publisher in 1694 of the first Swedish book of hymns. Svedberg represents a widespread form of downto-earth religiosity, which had taken its manifest expression in the Pietistic movement with a heritage of devotional reading of authors such as Johann Arndt (1555-1621) and Christian Scriver (1629-1693). (Lamm 1915, 2.) In the first half of the eighteenth century, the existence of God and the principles of Christianity were still taken by most scientists as self-evident, and as not necessarily conflicting with the progress of science or with scientific methods. (See Olson 2006, 111-36.)

Since the late seventeenth century a new scientific attitude had slowly emerged, as seen most clearly in the Philosophical Transactions of the Royal Society and in scientific communities and periodicals with a similar stance; one such was Daedalus Hyperboreus, founded in 1716 by Swedenborg and Christopher Polhem. In this rising empirical discourse the search for truth had become more properly a search for evidence, with particular stress on communicability in the form of empirical demonstration and the sharing of results. Another important feature concerned the necessity of the investigator's disinterestedness as a guarantee of truthfulness, thus rejecting all forms 
of fanaticism or enthusiasm. (Dear 1992.) Swedenborg was in many respects a true representative of this emerging scientific culture, as a member both of an elite of prominent scientists and of the Swedish aristocracy, serving his country in the House of Nobles.

The rationale of Swedenborg's theology is a conveying of the true meaning of the Scriptures by way of a system of correspondences, presented in his eight-volume Arcana Coelestia (1749-1756). The most fascinating and remarkable parts, however, were the passages entitled Memorabilia, which appeared in many of his later works and which contained descriptions of communications with spirits and visits to the regions of Heaven and Hell. Immanuel Kant's (1724-1804) Dreams of a Spirit-Seer (1766) was based on Arcana Coelestia, which partly ridiculed him. Yet, as Gregory R. Johnson has shown, Swedenborg also had a positive influence on Kant; one example is the concept of a 'Kingdom of Ends', which is related to and largely derived from Swedenborg's idea of the two juxtaposing worlds (Johnson 2009).

The created world, in the Swedenborgian universe, is a set of signatures pointing to more perfected entities on the spiritual side. In True Christian Religion (Vera Christiana religio 1771) Swedenborg sums up his theology as follows: it is impossible to define the essence of God, but it is possible to grasp His primary qualities, love and wisdom (amor et sapientia). 'In the spiritual world this essence of God is represented by the spiritual sun, the warmth of which is love and the light of which is wisdom: thus it is the prototype of our natural sun.' (Jonsson 1988, 41-2.) In interpreting the relationship between the spiritual and the natural Swedenborg utilizes the old doctrine of correspondences, which offers a systematic framework 'in which literally every single phenomenon communicates a spiritual message or is a token of divine love and wisdom', as Inge Jonsson $(1988,39)$ puts it. Swedenborg's theology maintained an analogical or correspondential notion of the interaction between words and things and supported a theistic orientation. There are close parallels to many Swedenborgian themes in the Romantic movement, but it also remained attractive as a spiritual philosophy in its own right, as shown by its impact on literature and arts in the nineteenth century. ${ }^{3}$

3 The list of these artists and writers usually includes William Blake, Honoré de Balzac, Edgar Allan Poe, Walt Whitman, Charles Baudelaire, Fyodor Dostoevsky and José Luis Borges (see e.g. Brock 1988; Williams-Hogan 2008, 256). For Swedenborg's influence on Strindberg, see Stockenström 1988. 


\section{Early Swedenborgianism in Finland}

Emanuel Swedenborg's influence in Finland is still by and large an unexplored domain. The reception of his ideas is furthermore of a distinctive kind, due to the country's close historical links with Sweden and to certain cultural and national trends that were accentuated after 1809, when Finland became a Grand Duchy of the Russian Empire. During the eighteenth century, Swedenborg's influence on Finland was strictly speaking part of his impact on his native soil. Finnish learned culture stood at the time in close affinity with the scholarly and religious milieu in Sweden; most of the educated classes in Finland, if not originally from Sweden, had at times lived there for educational or other reasons.

The most prominent among Swedenborg's friends in Finland was Carl Fredrik Mennander (1712-1786), a student of Linnaeus' and Professor of Physics at the Academy of Turku, later Bishop of Turku and finally Archbishop of Uppsala in Sweden. Mennander was deeply learned and possessed the largest library in Finland of its time. Their correspondence shows that Swedenborg had great confidence in Mennander, sending his new publications to him as well as to the Library of the Academy of Turku. (Mennander 1939-1942; Smithson 1841, 226-30.) When the Library burnt down in the Great Fire of Turku in 1827, with a loss of approximately 40000 volumes, the losses included a large collection of Swedenborg's work.

From the 1770s onward the most influential Finnish Swedenborgians were the Nordenskjöld brothers, August (1754-1792) and Carl Fredrik (1756-1828), who edited and published Swedenborg's manuscripts. Both were ardent promoters of Swedenborg's doctrines and established contacts with like-minded individuals at home and abroad, also participating in the first Swedenborgian conference, held in London in 1789. ${ }^{4}$ Due to the efforts of the Nordenskjölds and their associates, Swedenborgianism also had an early impact among officers in the Finnish army stationed at the fortress of Suomenlinna (Swedish Sveaborg) outside Helsinki. (Rein 1939; Smithson 1841; Siukonen 2000.) The last decades of the eighteenth century were marked to a large extent by the debate between the advocates of Voltairean enlightenment and the mystics, notably Freemasons, Mesmerists and Swedenborgians. It is worth noting that the most challenging opposition to

4 The conference was also attended by William Blake and his wife Catherine (Schuchard 1992).

5 This was lamented by the learned historian and classical scholar Henrik Gabriel Porthan (Rein 1939). The early history of the fortress with regard to Swedenborgianism is still to be written. Carl Fredrik Nordenskjöld the elder, father of the brothers Nordenskjöld, served as a military engineer in constructing the fortress, and was himself a Swedenborgian. (Nyberg 1927, 426-7.) 
the former, represented by Porthan and his student Johan Henrik Kellgren (1751-1795), came almost solely from Swedenborgians. (Rein 1939. ${ }^{6}$ The followers of the Swedish visionary were thus considered to be the most significant opponents in the debate, a controversy in which neither side was willing to retreat. In the course of the debate Kellgren coined the expression 'One does not possess genius for the sake of being insane' (Man äger ej snille för det man är galen), pointing to Swedenborgians as well as to spiritualistic tendencies in general. The fierceness of the controversy is shown in the fact that Carl Fredrik Nordenskjöld continued to attack Kellgren long after the latter's death, by for instance publishing a highly critical German biography of him in order to prevent the budding interest in his works in Germany. (Lagus 1884, 256-60.)

\section{Runeberg and Swedenborg}

While the early history of Swedenborgianism in Finland is marked by zealous followers and a military setting, from the early nineteenth century onward his reception appears to have become more of a curious reading by the educated classes. At this point the young Johan Ludvig Runeberg also enters the stage. Although there is no evidence that Runeberg actually read Swedenborg, he was almost certainly indirectly influenced by him, through friends and through literature. This conjecture is supported by recapturing two important aspects of Runeberg's life.

Runeberg matriculated at the Academy of Turku in 1822, five years prior to the Great Fire of 1827. In the same year Johan Vilhelm Snellman (1806-1881), who later was to introduce Hegelianism to the country and assume the title of Finland's national philosopher, commenced his studies as well. Runeberg and Snellman became more closely acquainted early in 1826, brought together by the poet Johan Jakob Nervander (1805-1848), ensuing in a life-long and mutually supportive friendship. (Viljanen 1949, 122-3.) When the Academy shortly afterwards moved to Helsinki, the new capital, the two young scholars came to share not only the same residence in the new settlement, but - due to a lack of furniture - even the same bed. Snellman's father, the Sea Captain Christian Henrik Snellman (1777-1855), was a known Swedenborgian and self-taught philosopher after his own fashion. The father also made frequent efforts to convert his son to Swedenborgian philosophy and spiritualism; this influence is notably witnessed in

6 Including the controversy between Kellgren and the philosopher Thomas Thorild, as the latter also advocated Swedenborgian principles. 
a brief essay written by Snellman during the time in Turku, presumably his first literary attempt: this was an independently composed treatise, Teosofin, världen och människan, influenced by Swedenborgian ideas. (See Jalava 2006; Manninen 1995; Savolainen 2006; Snellman 2005.) The precise date of the essay is uncertain, but it is safe to say that the immediate surroundings of the young Runeberg included efforts to grapple with Swedenborgian issues.

The other relevant point was the huge impression and enduring literary influence exerted on Runeberg by the poet, novelist and social reformer Carl Jonas Love Almqvist (1793-1866). Runeberg's friendship and affiliation with Almqvist has intrigued scholars, not least his continuing respect for the Swedish novelist even after the latter had to flee Sweden in 1851, suspected of fraud and attempted murder. (Wrede 2005, 237.) Almqvist's profound leaning on Swedenborg in his production has always been beyond dispute, having as its central themes the Swedenborgian concepts of love, marriage and the equality of sexes. In Swedenborg's theology conjugal love is sanctioned from above and fulfilled in the afterlife. True marriages, or marriages in a new religious spirit, according to Almqvist, would inaugurate the kingdom of God on earth and allow conjugal love to descend from heaven. (Hjern 1988, 80-2, 85.) ${ }^{7}$ Almqvist therefore proposed a form of Swedenborgian chiliasm similar to August Nordenskjöld's social and utopian endeavors, in which the doctrine of conjugal love, fused with alchemical theory, resulted in a schism among the participants at the Swedenborgian conference in London in 1789. This early schism, seemingly too recent and too shameful for Robert Hindmarsh to recapture in his otherwise informative Rise and Progress of the New Jerusalem Church (1861) was, however, due mainly to the fact that Swedenborg's work was at the time only partially known. (Schuchard 1992.)

The best-known and most controversial of Almqvist's works was Det går an ('It might be allowed') from 1839, a description of a couple living in a free, open and mutually supportive friendship beyond all societal constraints. Almqvist's main rationale and Swedenborgian precept is that true conjugal love transcends the boundaries of formal or institutionalized marriage; a marriage lacking conjugal love is artificial. For this reason, and in certain cases, concubines can be accepted, a precept which August Nordenskjöld had evidently also followed (Häll 1995, 137). Almqvist's work had a huge

7 Olle Hjern provides a list of probable influences of Swedenborg on Almqvist, such as his grandfather Carl Christoffer Gjörwell, who had personally met Swedenborg, and his uncle Erik Abraham Almqvist. Some of his teachers and fellow-students at Uppsala University were also Swedenborgians. (Hjern 1988, 80-1.) 
impact on the generation of Runeberg and Snellman, and their friend Zacharias Topelius later recalled the appearance of the Swedish novelist as a bolt of lightning from a clear blue sky. Almqvist's romantic works, especially Törnrosens bok, was admired by both Johan Ludvig Runeberg and his wife Fredrika Runeberg. (Viljanen 1949, 433-4; Wrede 2005, 237-44.) During a brief but intense period Almqvist's anti-matrimonialism in Det går an also occupied the mind of J. V. Snellman, who acknowledged the novel's central character, Sara Videgren, as 'Sweden's foremost philosopher', but nevertheless felt forced to write a sequel to the novel with a tragic ending (Snellman 2005).

\section{Words and Things}

A chief source for Runeberg's religiosity, his views on nature and man's place in nature, are his Letters From an Old Gardener (Den gamle trädgårdsmästarens brev). Runeberg wrote the Letters - short stories in epistolary form between 1836 and 1838 as a retort to the growing influence of the Pietistic revival movement; they were originally published, in the form of three articles and a reply, in the newspaper Helsingfors Morgonblad. Runeberg positions himself in the Letters in opposition to one contemporary Pietistic view of the natural world, which tended to stress the desolation of nature due to the Fall. The conversation in the Letters is part of a prolonged confrontation of two different religious types or minds, a natural-Romantic approach and a biblicistic and puritan one, represented by a former friend and poet, the Pietist Lars Stenbäck (1811-1870). In a reply to Runeberg, Stenbäck, who had come to reject art and poetry as unchristian, charged Runeberg with knowing nothing of being a Christian. This ultimately put Runeberg in a defensive position, leading him to offer a theological justification of his view, which saw Pietism as a larger threat within culture and the university. (Krook 1928; Wrede 2005, 223.)

In the Letters, generally considered to be his most brilliant prose work, Runeberg discusses various facets of his religious views. One particular theme is his description of words as corresponding to things. This theme, as we shall see, belongs more generally to the topos of the liber naturae, the 'book of nature'. Runeberg had hinted at this theme already in The Midsummer Feast (Midsommarfesten) from 1827, where he uses the expression 'nature's delightful book of devotion' (Runeberg 1949, 18). In the Letters Runeberg elucidates the theme in an attempt to demonstrate his view on the prerequisites of devotion and knowledge. This passage in the Letters 
has been subject to diverse interpretations, as well as in some cases partial misinterpretations. On the whole, however, it has been only briefly discussed and has not been regarded as being central to Runeberg's world-view. The main passage in the Letters is as follows:

To look into the world not being able to discern the things that are in it, not having words and names for them, is to look into a sun or a night, where everything coalesces into each other; hence says the revealed Word: such things are in God and in the Creation, look and perceive it for your devotion and peace! But if I [...] may use a simpler idiom and compare great things with small, I will place in your hand this book, which contains a register of those flowers and herbs we cultivate every summer. If you now imagine that you have never seen such [flowers and herbs], nor would you be able to raise your gaze from this book to watch them in their growth and blooming, then you could, as long as you live, read their names but would not gain any piety or knowledge. Likewise, it would be useless, in the course of the summer, to watch this garden if you were unable to discern one flower from another, or, what is the same thing, had no names for them and their properties. The word, therefore, needs the thing and the thing needs the word, and both must be sought and found in each other. One should, then, not only read but also dwell within and behold the world of God, and there perceive His word in life and creation and in faith and thought, such as we every summer can, so to speak, see the words in this book blossom and live in our garden. (Krook 1928, 37-8.) $)^{8}$

Runeberg's figurative expression obviously leaves room for some ambiguities with respect of the 'book', slipping as he seems to from one meaning to another: from Scripture to a 'register' of 'flowers and herbs', and finally

8 'Att se in i världen utan att urskilja de föremål, som i den finnas, utan att äga ord och namn för dem, det är som att se in i en sol eller en natt, där allt sammansmälter i vartannat; därför säger det uppenbarade ordet: sådant finnes i Gud och skapelsen, se och förnim det till din uppbyggelse och frid! Men om jag [...] får bruka ett enfaldigare sätt och likna stora ting vid små, så ville jag giva er i handen denna bok, som innehåller en förteckning på de blommor och örter, som vi alla somrar plägat odla. Om ni nu föreställer er, att ni aldrig sett sådana och icke heller finge se opp från denna bok för att betrakta dem i sin växt och blomning, så kunde ni läsa, så länge ni lever, deras namn och skulle dock ingen uppbyggelse och kunskap vinna. Likaså vore det eder onyttigt att sommaren igenom hålla edert öga på denna trädgård, om ni icke urskilde den ena blomman från den andra eller, vad som är detsamma, hade namn på dem och deras egenskaper. Ordet behöver därför saken och saken ordet, och båda måste i varandra sökas och finnas. Därföre må man icke läsa endast, utan även leva och skåda in i Guds värld och där se hans ord i liv och verk, i tro och tanke, såsom vi varje sommar kunna se orden i denna bok liksom blomstra och leva i vår trädgård.' 
to a living book or the actual book of nature. His main point, however, is that words or names are useless and empty unless they are attached to factual, material things. Words thus have their counterparts in things, in the sense that they actually 'need' each other. In another sense, and by way of signification, words are things: the book of nature contains as many words as there are created things. 'We call the Bible the word', Runeberg writes: 'what other meaning could subsist therein, than that it contains, so to speak, words and designations of all those conditions that exist between God and his created work? If the word did not have its counterpart in the world, it would be an empty word resembling a name not representing anything in nature. ${ }^{\prime 9}$ (Krook 1928, 37.)

Runeberg employs the book metaphor both in a broad context of nature as a set of signifiers and in a vitalistic style, which is close to the early pietistic tradition expounded in Johann Arndt's Four Books on True Christianity (1605-10). Belfrage points to this heritage in Runeberg's religious thinking, especially manifest in the Letters, asserting that in the eighteenth century religion was commonly discussed in natural and organic terms: 'It was perceived more often as a naturally grown plant, nourished by the saps of the earth and tended by human culture, than as the gracious message of joy from Heaven' (Belfrage 1917, 139).

Within the topos of the liber naturae, language was strongly anchored in what has been termed an 'emblematic world view' ${ }^{10}$ The concept of the book of nature, initially developed in the writings of the Early Church Fathers, received its authoritative position as an important correlative to Scripture in the High Middle Ages. (Curtius 1990, 319-26; Glacken 1997, 203-4; Harrison 2001.) Constituting two distinctive but interrelated sources of knowledge, the two books made it possible for man to receive a more accurate and deeper understanding of nature and of man's salvation. The book of nature, however, had been rendered obscure after the Fall. As a result of Original Sin, nature had become mute and opaque for man. From the point of view of man's knowledge of created things, this was evident in the fact that nature does not disclose itself immediately to us: the Creation has to be decoded. (Bono 1995; Harrison 2002.)

9 'Vi kalla ju bibeln ordet; och vilken annan mening kan därunder ligga än den, att den innehåller liksom ord till och benämningar på alla de förhållanden, som förefinnas mellan Gud och hans skapade verk? Skulle nu ordet icke hava sin motsvarighet i världen, så vore det ett tomt ord och skulle likna ett namn, som icke betecknade någonting i naturen.'

10 See Ashworth 1993 and for further discussion Bono (1999) and Westerhoff (2001). Historians of linguistics have described the change from an emblematic world view to a modern one as the 'decontextualization' of the world (Ashworth 1993, 318). 
In the Sturm-und-Drang movement the book metaphor was employed among others by Herder, Goethe and Jakob Grimm (Curtius 1990, 324-6). It is in the philosophy of Johann Georg Hamann (1730-1788), however, that the topos is most consistently developed. Hamann was extremely influential as a disseminator of ideas and themes in the Romantic movement. In 1757 in London Hamann had experienced a religious conversion, of which he wrote in his Thoughts about the Course of My Life in 1785 that he felt his 'heart beat' and 'heard a voice in its depths' (Wessell 1969, 434). Runeberg, who was well acquainted with the writings of the German Romantics, was most certainly familiar with Hamann's views as well, including his Biblically oriented theism and his conception of nature as a book. In his reply (The Last Will and Testament of the Knight of the Rose-Cross 1772) to Herder's prize-winning treatise On the Origin of Language, Hamann wrote that in the beginning

[e]very phenomenon of nature was a word, - the sign, symbol, and pledge of a new, secret, inexpressible but all the more fervent union, fellowship, and communion of divine energies and ideas. All that man heard at the beginning, saw with his eyes, looked upon, and his hands handled was a living word; for God was the Word. With this word in his mouth and in his heart the origin of language was as natural, as close and easy, as a child's game. (Hamann 2009, 108-9.)

In Aesthetica in nuce (1761) Hamann says that ' $[\mathrm{t}] \mathrm{o}$ speak is to translate - from an angelic language into a human language, that is, to translate thought into words, - things into names - images into signs, which can be poetic or curiological, historic or symbolic or hieroglyphic' (Hamann 2009, 66). Language pervades the universe in a multi-layered fashion. There is an original language, lost in history, yet existing in the present order and thus attainable for man; the more interior the more perfect and universal. The perfect language exists only in God, and the closer to Him, the more words represents pure ideas.

A logocentrism similar to Hamann's is deep-seated in the theology of Swedenborg. As the Creation originates in the Word of God, words and language ultimately constitute the order. The Word has a real connection with the created things, it is 'the veriest reality' and 'the source of all things, and from which are the forms of good and of truth' (Arcana Coelestia § 5272:2). Swedenborg also pays attention to different forms of speech. God is Word, and accordingly also Speech, and speech is found on several planes in the 
universe. In the three heavens language and speech ascend from exterior to interior, becoming yet more perfect and universal. The spirits' language, Swedenborg maintains, 'is not a language of words, but is a language of ideas of thought; and this language is the universal of all languages' (Arcana Coelestia § 1637:2):

But the speech of angels is ineffable, far above the speech of spirits, for it is above that of angelic spirits, and is not intelligible in any way to man so long as he lives in the body. Nor can the spirits in the world of spirits form any idea of it, for it is above the perceptive power of their thought. This speech of angels is not of things represented by any ideas like those of spirits and angelic spirits; but it is a speech of ends and of the derivative uses, which are the primaries and the essentials of things. [...] The speech of the celestial angels is distinct from that of the spiritual angels, and is even more ineffable and inexpressible. The celestial and good things of ends are what their thoughts are insinuated into, and they are therefore in happiness itself; and, wonderful to say, their speech is far more abounding, for they are in the very fountains and origins of the life of thought and of speech. (Arcana Coelestia $\S 1645,1648$.

The heavenly or spiritual order has a counterpart in the historical process. In primordial times there was an original language where words and things were still united. This theme is expounded at length in a work contemporary with Runeberg's Letters, namely the illuminating and enigmatic Nature (1836) by Ralph Waldo Emerson (1803-1882). Emerson's examination of the correspondences between words and things stems to a significant degree from his personal acquaintance with an early nineteenth-century Swedenborgian, Sampson Reed, and his reading of the French Swedenborgian eccentric Guillaume Oegger (Hodder 1989, 13). A comparison of Runeberg with Emerson not only reveals a parallel complex reading of nature, but also displays similar views on the relationship and interaction between words and things. 'Every word which is used to express a moral or intellectual fact, if traced to its root, is found to be borrowed from some material fact', writes Emerson. The elemental language originally attached to natural things is, however, buried in history: 'Most of the process by which this transformation is made, is hidden from us in the remote time when language was framed.' (Emerson 1849, 23-4.) Or, in the words of Sampson Reed: 'Had we a history of poetry from the first rude effusions to where words make 
one with things, and language is lost in nature, we should see the state of man.' (Cit. in Hotson 1929, 262.) Words are signs of natural facts, which in turn are signs of spiritual facts.

\section{Light is My Guide}

The two worlds have their correlatives in the outer and inner man. According to Swedenborg, '[t]he internal man is called the spiritual man, because it is in the light of heaven, which light is spiritual; and the external man is called the natural man, because it is in the light of the world, which light is natural'. (True Christian Religion 1771, § 37-38.) In the opening letter from Runeberg to von Beskow, the poet writes: 'I have thought that there are two sides in man: an internal that unites her with everything that exists and an external that determines her distinctiveness, makes her a specific and unique self.' The internal side constitutes man's spiritual life and contains organs that are not yet discovered, whereas the external part embraces his conceptual life with its senses. In different persons one or the other of the two sides is dominant. This leads, Runeberg maintains, to a division into two types or extremes, the 'day-type' and the 'night-type'. The former is characterized by clear and sharp contours, but is also controlled and limited. The latter mind-set has twilight, gloom, where things tend to dissolve in the dark, but is also distinguished by zealous commitment. (Runeberg 1879, 279.) ${ }^{11} \mathrm{~A}$ balance or harmony is needed; an overly rational mind leads its possessor astray as much as a mind plunged into moods or feelings alone. While the passage relates to his personal understanding of Swedenborg, Runeberg here actually elucidates a variety of Romantic themes inherent in or part of the mainstream spirituality of the mid-nineteenth century. ${ }^{12}$ The call for a balance between the outer and inner man is in any case fundamental to a Swedenborgian approach as well. Emerson writes in Nature that ' $\mathrm{t}$ ] he lover

11 'Jag har tänkt mig hos menniskan två sidor, en inre, som förenar henne med alltillvarelsen, och en yttre, som bestämmer hennes särskildhet, gör henne till ett för sig varande, bestämdt jag. Till den inre hör hennes andelif med dess ännu oupptäcta organer, till den yttre hennes begreppslif med dess tjenare, sinnena. Hos olika personer ser man endera af dessa sidor hafva öfvervälde. Deraf söndrandet, redan, den klara begränsningen, den själviska beräkningen hos den ena; förblandningen åter, svävandet, den dunkla aningen, den hängivna uppoffringen hos den andra; dagtycket, om jag så får säga, med dess klarhet och skarpa konturer hos den förra, natt-tycket med dess skymning och försmältning af föremålen hos den sednare.'

12 The 'inner senses' was a commonplace figure of speech used by Romantic writers. Coleridge, for instance, was much occupied by its various meanings and interpretations. (Lyon 1966.) The 'day-type' and the 'night-type' show a strong affinity with Novalis' 'Hymns to the Night', although Novalis' 'dark night' occupies a higher place in the dichotomy. Runeberg employs a 'golden mean', a middle way between the two extremes. 
of nature is he whose inward and outward senses are still truly adjusted to each other' (Emerson 1849, 7). It will need a tuning of the inward and outward senses to rightly apprehend the grammar of the world. Emerson maintains that '[a] life in harmony with nature, the love of truth and of virtue, will purge the eyes to understand her text. By degrees we may come to know the primitive sense of the permanent objects of nature, so that the world shall be to us an open book, and every form significant of its hidden life and final cause.' (Emerson 1849, 33.)

A frequently employed trope in Runeberg's lyrics, pointed out by a number of scholars, is the metaphor of light, ${ }^{13}$ whereby in the Letters he conveys a dialectical understanding of words and things. The 'word' may consist of mere words, or 'dead letters', just as it can also be a living word of spirit. Concomitantly, the world can be dark and sterile, containing mere things, just as it can also 'breath around us' and be a 'holy source for peace and comfort'. Nature, like Scripture, is a 'living revelation of God'. Thus Scripture is understood only when 'the spirit of divine truth shines toward us' from words and sentences; things in turn are perceived for the reason that from them 'a beam of the light of eternity radiates toward us'. As both word and thing are part of revelation, they also connect to each other. The world encloses the teachings of Scripture 'like a thing in itself contains all the truths that can be said about it'. (Krook 1928, 38-9.)

Just as the inner creative word of God informs the mind of man through correspondences, natural processes operate directly as signifiers of spiritual facts. The Creation informs or 'speaks to' man through changes, alternations and procedures. Thus, every appearance in nature, 'every hour and change' corresponds, in Emerson's view, 'to some state of the mind, and that state of the mind can only be described by presenting that natural appearance as its picture'. (Emerson 1849, 24.) Runeberg similarly links natural and psychic processes in terms of emotions and moods corresponding to visible changes in nature (Ahokas 1997, 42). In his much-loved poem 'By a Spring' (Vid en källa) the soul is associated with a spring; the passing clouds reflected in its surface are related to moods of joy and sorrow. In

13 Runeberg uses the metaphor in its traditional sense, distinct from the predominant Enlightenment metaphorical representation of light: 'The Enlightenment inherited the traditional metaphor linking the image of light with knowledge but gave it an entirely new form. The light of Enlightenment was not the dazzling mystical light of Platonic Being, nor the radiance of the Christian God, nor even the divinely inspired "natural light" of reason discussed by thinkers such as René Descartes and Nicolas de Malebranche in the seventeenth century. For the Enlightenment, the light of a human reason alone would dissipate the mists and shadows of past tradition and superstition.' (Bates 2001,4.) 
another poem, 'The Church' (Kyrkan), Runeberg portrays an old man in boat, who loses his way on the lake because of the fog and fails to attend Sunday mass. As the distant church bells ring the sun breaks forth, making the fog fade away and illuminating the landscape, island after island, one headland after another, until the world abounds in color, brightness and beauty. Finding devotion is thus not confined to the written word alone, or to participating in a Church ceremony: all of visible Creation, through correspondences, communicates the living word. This reverential stance is of course not exclusively Swedenborgian; it was characteristic of most Romantic philosophy, in particular of Hamann, who similarly to Runeberg has been labeled Pantheist and Panentheist. ${ }^{14}$ The idea that nature provides a universal learning, open to all, is ultimately an intrinsic part of the topos of the liber naturae. This universal learning is received, wrote John Chrysostom (c. 349-407), 'from contemplating the alternation of day and night, the order of seasons [...] the relation of land to the sea, and the balancing powers of nature'. (Glacken 1997, 203.)

Against the backdrop of nature's textuality, however, there are themes in Runeberg that more strikingly accord with a Swedenborgian approach. Runeberg recurrently uses the theme of light as a metaphor for guidance, taking as his maxim Lux mea dux, light is my guide. (Viljanen 1948, 33-43.) In the letter to von Beskow he employs light and darkness, day and night, as metaphorical representations of the inner and outer, of spirit and nature:

Do we not sense ourselves as located in an inner, though by mind and senses uncharted, connection with world and beings around us. Should not this feeling enable us to attain full perception, when the stronger gleam is extinguished by which thought and senses come to the surface and blind us? We should in vain tell of a starry heaven to one who lived in a continuous day, he would believe us to be telling ghost stories; But let the day die out around him and he shall see innumerable worlds exist and shine, he will be able to identify their places and give the name of reality to that which for him previously not even had the credence of a dream. ${ }^{15}$

14 For Hamann, theology is grammar (Hamann 2009, xiii). Hamann and Runeberg were both submitted to a Biblically oriented theism, which strictly speaking evades pantheism (Cf. O'Flaherty 1958, 48).

15 'Känna vi oss icke stå i en inre, ehuru af förstånd och sinnen outredd förbindelse med verld och varelser omkring oss. Hvarför skulle icke denna känsla kunna klarna till full skådning, då det starkare sken vore släckt, hvarmed tanke och sinnen öfverflygla och blända oss? Vi skulle förgäfves tala om en stjernhimmel för den, som lefde i en beständig dag, han skulle anse oss berätta spökhistorier; men låt dagen slockna kring honom och han skall se de otaliga verldarna finnas och lysa, han skall kunna utpeka deras platser och gifva namn af verklighet åt hvad förut för honom icke ägt ens vikten af en dröm.' (Runeberg 1879, 280.) 
The inner spiritual world is a distinctive state of mind, open to experience through the inner senses; or, as Runeberg also expresses it, through 'organs that are not yet discovered'. But it is a facility that only prophets or seers would claim to possess. The closest to an 'account' of the spiritual world in the writings of Runeberg might be his 'Fragment of a greater poem', an unfinished narrative portraying a criminal or a kind of superman in the afterlife, probably inspired by Almqvist's Ferrando Bruno (Viljanen 1948, 183). Sounds and words play a prominent part in the world of this solemn, unemotional and solitary being. A question is posed, whether he is 'mature, or is there a bond,/ that still binds him to nature/ And impels him with laws of an order?'16 The word 'come', which in the poem is a 'dark' and 'horrible word', echoes from everywhere in the world of spirits or angels. The story aims at a redemptive ending: as the word 'come' is ultimately a word of love.

In Runeberg's poetry the spiritual world most often places its imprint on nature or the visible Creation. The following passage from Letters has a particularly Swedenborgian stance, not only through the metaphor of light but in its correlation of the beautiful and the true in the angelic realm: ${ }^{17}$

When all breezes had waned and the lake reflected every color of the flowers on earth, and the sun by its light embraced all this, you smiled and asked me, which is more beautiful, the earth or Heaven. [...] a hymn of praise it was such as when angels sing, since the service of angels is an enjoyment of something beautiful and true. At this, your sentiment could comprehend the beauty and the truth laid open for your eyes, as it radiated towards you from the whole of Creation, and the earth was for you as delightful as Heaven. (Krook 1928, 16.)

Perhaps the most compellingly Swedenborgian piece of work, however, would be the last poem Runeberg wrote, in 1875 at the age of 71: the only poem he wrote during the long years after he had suffered a stroke and was confined to his bed. He wrote it, moreover, with his left hand, as his right side had become paralyzed. It is a short prose poem called 'The lily of the valley' (Liljekonvaljen):

16 'Säg, är han mogen, eller fins ett band,/ Som binder honom vid naturen än/ Och drifver honom med en ordnings lagar?' (Runeberg 1935, 194.)

17 'När då varje fläckt lagt sig, och sjön speglade jordens alla blomsterfärger, och solen i famnen av sitt ljus omslöt allt detta, då log du och frågte mig, vilkendera var vackrare, jorden eller himmelen. [...] en lovsång var det sådan som änglar sjunga, ty änglars gudstjänst är en glädje over någonting skönt och sant. Då kunde din känsla fatta skönheten ännu, och sanningen låg klar för dina ögon, ty den strålade emot dig från skaparens hela värld, och jorden var dig då ljuv såsom himmelen.' 
Once I dreamt I was in heaven. There I saw everyone, felt the scent of all the flowers that were dear to me before. But the earthly flowers were to the heavenly as if they had grown in moonlight instead of sunlight. The lily of the valley alone was alike, both in Heaven and on earth. The same color of innocence, the same perfume up there as down here, but here only a few days in springtime, there the whole year around..$^{18}$

In the poem Heaven is depicted, as in the visions of Swedenborg, with a material and sensual side; a world informed through tastes, smells and visual perceptions, and inhabited by human beings. In the Swedenborgian Heaven, or afterlife, flowers can be touched and smelled, food can be eaten and bodily pleasures can be enjoyed. (See e.g. Heaven and Hell 1758, $\S 421-431$; Lang 1988, 314-5.) 'The Lily of the valley' thus gives us a glimpse of the heavenly order where 'all things exist in a state of greater perfection', undisturbed by earthly variables.

\section{Conclusions}

From a modern perspective Runeberg was a man of faith, a fundamentalist indeed. He was guided by God's Word, residing in his conscience or heart, but also in the visible Creation. The Creation is stained by Original Sin, manifestly so in the division between words and things, the inner and the outer. Man needs to 'dwell within and behold the world of God' in order to reconcile them, thus, in the form of the image of God, restoring the Creation. What ultimately keeps words and things together is that both stem from God, delivered through his two books.

Faith and love are the primary faculties man should lean on in order to act and live as a Christian. Reflecting traits from both Romantic and early modern devotional literature, nature also involves a paradisiacal aspect. In order to perceive this 'reconciled' aspect, reading the book of nature requires faith and devotion; through faith one receives grace, which endows the believer with a capacity to perceive God's presence in his heart and in the world. Thus, while the world can signify that which is fallen and lost,

18 'En gång drömde jag att jag var i himlen. Der såg jag alla, kände doften af alla blommor, som voro mig kära förr. Men de jordiska blommorna voro mot de himmelska, som om de vuxit i månsken i stället för solljus. Liljekonvaljen ensam var sig lik, både i himlen och på jorden. Samma oskuldsfärg, samma vällukt der uppe som här nere, men här blott för några dagar om våren, der för hela året om.' (Runeberg 1878, 234.) 
'it can also signify the blessed and reconciled world, just as the word can mean the dead letter, but also the spiritual word' (Krook 1928, 38).

Runeberg's epistemic understanding of words and things places him in the same emblematic or pansemiotic ${ }^{19}$ tradition as Swedenborg. Within this 'Classical discourse', words and things seek to be redeemed or conjoined. In The Order of Things, Foucault writes:

One might say that it is the Name that organizes all Classical discourse; to speak or to write is not to say things or to express oneself, it is not a matter of playing with language, it is to make one's way towards the sovereign act of nomination, to move, through language, towards the place where things and words are conjoined in their common essence, and which makes it possible to give them a name. (Foucault 1994, 117.)

The emblematic world view and linguistic theory, though in a process of 'decontextualisation' from the early seventeenth century onwards, continued well into the nineteenth century. ${ }^{20}$ The world of Runeberg is an emblematic world. Natural things and processes are emblems, or types, pointing to spiritual entities or processes which can be identified and correlated. It is mainly against this larger backdrop that a Swedenborgian influence should be understood and evaluated in Runeberg's production. His recurrent interest in the angelic realm, its nearness, as well as a certain movement and crowding of the spirit world, are features which were largely informed by nineteenth-century Swedenborgianism. This interest and understanding is furthermore underpinned by a theistic orientation, in which the angelic or spiritual realms are penetrated in a literal sense by God's word, and accordingly also by different modes of languages and speeches.

\footnotetext{
19 See Westerhoff 2001.

20 'For nineteenth-century philology such analyses remained, in the literal sense of the word, a "dead letter". But not so for a whole way of experiencing language - at first esoteric and mystic at the time of Saint-Marc, Reveroni, Fabre d'Olivet, Oegger, then literary when the enigma of the word re-emerged in all its density of being, with Mallarmé, Roussel, Leiris, or Ponge.' (Foucault 1994, 103.)
} 
Bibliography

Ahokas, Jaakko

1997 (1973) A History of Finnish Literature. Richmond: Curzon Press. (Indiana University Publications, Uralic and Altaic Series, Volume 72.)

\section{Ashworth, William}

1993 Natural History and the Emblematic World View. - David Lindberg \& Robert Westman (eds), Reappraisals of the Scientific Revolution, 303-32. Cambridge: Cambridge University Press.

Bates, David

2001 Idols and Insight: An Enlightenment Topography of Knowledge. -Representations, 73 (Winter, 2001), 1-23.

\section{Belfrage, Sixten}

1917 Johan Ludvig Runeberg i sin religiösa utveckling. Uppsala: J. A. Lindblads Förlag.

\section{Bergquist, Lars}

2005 (1999) Swedenborg's secret. The Meaning and Significance of the Word of God, the Life of the Angels, and Service to God. A Biography. London: The Swedenborg Society.

\section{Beskow, Bernhard von}

1858 Minne öfver assessoren i Bergs-Kollegium Emanuel Swedenborg. (Antryck ur av. Akad. Handl.) Stockholm: P. A. Norstedt \& söners förlag.

\section{Bono, James J.}

1995 The Word of God and the Languages of Man. Interpreting Nature in Early Modern Science and Medicine. Vol. 1. Ficino to Descartes. Wisconsin: The University of Wisconsin Press.

1999 From Paracelsus to Newton: The word of God, the book of nature, and the eclipse of the emblematic world view. - J. Force \& R. H. Popkin (eds), Newton and Religion: Context, Nature, and Influence, 45-76. Dordrecht: Kluwer.

Brock, Erland J. General Editor

1988 Swedenborg and His Influence. Bryn Athyn: The Academy of the New Church.

\section{Curtius, Ernst Robert}

1990 (1953) European Literature and the Latin Middle Ages. With a New Afterword by Peter Godman. Princeton: Princeton University Press. (Bollingen Series 36.)

\section{Dear, Peter}

1992 From Truth to Disinterestedness in the Seventeenth Century. - Social Studies of Science 22, 619-31. 


\section{Emerson, Ralph Waldo}

1849 (1836) Nature. Boston \& Cambridge: James Munroe and Company.

\section{Foucault, Michel}

1994 (1966) The Order of Things. An Archaeology of the Human Sciences. London: Routledge.

\section{Glacken, Clarence J.}

1997 (1967) Traces on the Rhodian Shore. Nature and Culture in Western Thought from Ancient Times to the End of the Eighteenth Century. Berkeley, Los Angeles, London: University of California Press.

\section{Hamann, Johann Georg}

2009 (2007) Writings on Philosophy and Language. Translated and edited by Kenneth Haynes. Cambridge Texts in the History of Philosophy. Cambridge: Cambridge University Press.

\section{Hansson, Karl-Johan}

2004 Var Runeberg religiös? - Pia Forssell \& John Strömberg (eds) Historiska och litteraturhistoriska studier 79, 69-82. Helsingfors: Svenska Litteratursällskapet i Finland.

\section{Harrison, Peter}

2001 (1998) The Bible, Protestantism, and the rise of natural science. Cambridge: Cambridge University Press.

2002 Original Sin and the Problem of Knowledge in Early Modern Europe. - Journal of the History of Ideas, 239-59.

\section{Hjern, Olle}

1988 Carl Jonas Love Almqvist - Great Poet and Swedenborgian Heretic. Erland J. Brock (ed.), Swedenborg and His Influence, 79-90. Bryn Athyn: The Academy of the New Church.

\section{Hodder, Alan D.}

1989 Emerson's Rhetoric of Revelation. Nature, the Reader, and the Apocalypse Within. University Park and London: The Pennsylvania State University Press.

\section{Hotson, Clarence Paul}

1929 Sampson Reed, a Teacher of Emerson. - The New England Quarterly, $2(2), 249-77$.

Häll, Jan

1995 I Swedenborgs labyrint. Studier i de gustavianska swedenborgarnas liv och tänkande. Stockholm: Atlantis.

Jalava, Marja

2006 J. V. Snellman: mies ja suurmies. Helsinki: Tammi. 


\section{Johnson, Gregory R.}

2009 From Swedenborg's Spiritual World to Kant's Kingdom of Ends. Aries 9 (1), 83-99.

\section{Jonsson, Inge}

1988 Swedenborg and His Influence. - Erland J. Brock (general editor), Swedenborg and His Influence, 29-43. Bryn Athyn, Pennsylvania: The Academy of the New Church.

\section{Kant, Immanuel}

2002 Kant on Swedenborg. Dreams of a Spirit-Seer and Other Writings. Edited by Gregory R. Johnson. West Chester, Pennsylvania: Swedenborg Foundation. (Swedenborg Studies 15.)

Krook, Tor (ed.)

1928 Runebergs Den gamle trädgårdsmästarens brev, Stenbäcks svar till den gamle trädgårdsmästaren och Runebergs Till författaren av Svar till den gamle trädgårdsmästaren ånyo utgivna med inledning av Tor Krook. Gamla Karleby: Kyrkans Ungdoms förlag.

\section{Lagus, Wilh.}

1884 Skalden Johan Henrik Kellgrens Finska Lefnadsminnen. Helsingfors: G. W. Edlund.

\section{Lamm, Martin}

1915 Swedenborg. En studie öfver hans utveckling till mystiker och andeskådare. Stockholm: Hugo Gebers Förlag.

\section{Lang, Bernhard}

1988 Glimpses of Heaven in the Age of Swedenborg. - Erland J. Brock (general editor), Swedenborg and His Influence, 309-38. Bryn Athyn, Pennsylvania: The Academy of the New Church.

\section{Laurila, K. S.}

1937 Ett Skede i en Evig Kamp. Striden mellan Runeberg och Stenbäck i idéhistorisk belysning. Helsingfors: Holger Schildts Förlag.

\section{Lyon, Judson S.}

1966 Romantic Psychology and the Inner Senses: Coleridge. - PMLA, 81 (3), 246-60.

\section{Mahlamäki, Tiina}

2010 Seitsemän veljeksen salattu maa. Emanuel Swedenborgin ideoiden läsnäolo Aleksis Kiven Seitsemän veljestä -teoksessa. - Sananjalka 52, $163-80$.

(forth.) The image of Emanuel Swedenborg in 19th century Finnish newspapers. - Conference Proceedings. The 9th EASR Conference on Messina, Italy, 2009. 


\section{Manninen, Juha}

1995 Härmän katekismus. Christian Henrik Snellmanin (1777-1855) swedenborgilais-mystinen maailmankuva. - Filosofia.fi. Portti filosofiaan. [http:// filosofia.fi/tallennearkisto/tekstit/2764]

Mennander, C. F.

1939-1942 K. F. Mennanderin lähettämiä ja saamia kirjeitä. Brev från och till C. F. Mennander I-III. Ed. by Kaarlo Österbladh. Helsinki: Suomen Historiallinen Seura. (Suomen historian lähteitä IV.)

\section{Nyberg, Paul}

1927 Eriksnäs - Herrgårdar i Finland. Nyland XI, 418-34. Helsingfors: Söderström \& Co. Förlagsaktiebolag.

O'Flaherty, James C.

1958 Some Major Emphases of Hamann's Theology. - The Harvard Theological Review, 51 (1), 39-50.

Olson, Richard G.

2006 Science and Religion, 1450-1900. From Copernicus to Darwin. Baltimore: Johns Hopkins University Press.

\section{Rein, Gabriel}

1939 Porthan ja 'valon viholliset'. - Historiallinen arkisto 46, 103-18.

\section{Ringbom, Lars-Ivar}

1954 Den himmelska skönhetens tragedi. - Historiska och Litteraturshistoriska Studier 30, 141-53. Helsingfors: Svenska Litteratursällskapet i Finland. (Skrifter utgivna av Svenska Litteratursällskapet i Finland 346.)

\section{Ruin, Hans}

1936 Mystiken hos Runeberg. - Historiska och Litteraturhistoriska Studier 12, 293-316. Helsingfors: Svenska Litteratursällskapet i Finland. (Skrifter utgivna av Svenska Litteratursällskapet i Finland CCLIV.)

\section{Runeberg, Johan Ludvig}

1878 Johan Ludvig Runebergs efterlemnade skrifter, I. Wiborg: Clouberg \& co. 1879 Johan Ludvig Runebergs efterlemnade skrifter, II. Wiborg: Clouberg \& co.

1934-1935 Samlade Skrifter av Johan Ludvig Runeberg. Andra Delen. Strödda Dikter I-II. Ed. by Gunnar Castrén \& Martin Lamm. Helsingfors: Svenska Litteratursällskapet i Finland. (Svenska Litteratursällskapet i Finland CCXLIV.)

1949 Samlade Skrifter av Johan Ludvig Runeberg. Tredje Delen. Episka Dikter. Ed. by Gunnar Castrén \& Martin Lamm. Helsingfors: Svenska Litteratursällskapet i Finland. (Svenska Litteratursällskapet i Finland CCXXIX:1.)

1973 Samlade Skrifter av Johan Ludvig Runeberg. Adertonde Delen. Kommentar 
till Brev. Ed. by Gunnar Tideström \& Carl-Eric Thors. Helsingfors: Svenska Litteratursällskapet i Finland. (Svenska Litteratursällskapet i Finland 455.)

\section{Savolainen, Raimo}

2006 Sivistyksen voimalla. J. V. Snellmanin elämä. Helsinki: Edita.

\section{Schuchard, Marsha Keith}

1992 The Secret Masonic History of Blake's Swedenborg Society. - Blakel An Illustrated Quarterly 26 (2), 40-51.

\section{Siukonen, Jyrki}

2000 Jälkilehtiä - Swedenborgin jälkivaikutus. - Emanuel Swedenborg: Clavis Hieroglyphica. Suomentanut ja johdannolla varustanut Jyrki Siukonen, 88-112. Helsinki: Gaudeamus.

Smithson, I. H. (ed.)

1841 Documents Concerning the Life and Character of Emanuel Swedenborg, late member of the House of Nobles in the Royal Diet of Sweden, assessor of the Royal Board of Mines, Fellow of the Royal Society of Upsala, and of the Royal Academy of Sciences of Stockholm, and Corresponding Member of the Academy of Sciences of St. Petersburg. Collected by Dr. J. F. I. Tafel. Manchester: Joseph Hayward, Market-Place.

\section{Snellman, Johan Vilhelm}

2005 J. V. Snellmanin kootut teokset. Helsinki: Valtioneuvosto. [http://www. snellman200.fi/kootut_teokset/fi.jsp]

\section{Stockenström, Göran}

1988 'The Great Chaos and the Infinite Order': The Spiritual Journeys of Swedenborg and Strindberg. - Erland J. Brock (ed.), Swedenborg and His Influence, 47-78. Bryn Athyn, Pennsylvania: The Academy of the New Church.

\section{Swedenborg, Emanuel}

1892 (1758) The New Jerusalem and its Heavenly Doctrine. Trans. John Whitehead. [http://www.sacred-texts.com/swd/tnj/tnj01.htm]

1900 (1758) Heaven and Hell. Trans. John. C. Ager. [http://www.sacredtexts.com/swd/hh/index.htm]

1905-1910 Arcana Coelestia. Trans. John F. Potts. [http://www.sacredtexts.com/swd/ac/index.htm]

1906 (1771) True Christian Religion. Transl. John Whitehead. [http://www. sacred-texts.com/swd/tcr/index.htm]

\section{Viljanen, Lauri}

1948 Runeberg ja hänen runoutensa 1837-1877. Porvoo: WSOY.

1949 Runeberg ja hänen runoutensa 1804-1837. Porvoo: WSOY. 
Wessel, Leonard P. Jr.

1969 Hamann's Philosophy of Aesthetics: Its Meaning for the Storm and Stress Period. - The Journal of Aesthetics and Art Criticism 27 (4), 433-43.

Westerhoff, Jan C.

2001 A World of Signs: Baroque Pansemioticism, the Polyhistor and the Early Modern Wunderkammer. - Journal of the History of Ideas 62 (4), 633-50.

\section{Williams-Hogan, Jane}

1998 The Place of Emanuel Swedenborg in Modern Western Esotericism. - Antoine Faivre \& Wouter J. Hanegraaff (eds), Western Esotericism and the Science of Religion, 201-52. Leuven: Peeters. (Gnostica 2.)

2005 Emanuel Swedenborg. - Lindsay Jones (ed.), Encyclopedia of Religion, 2nd ed. Volume 13, 8898-900. Detroit: MacMillan.

2008 The Place of Emanuel Swedenborg in the Spiritual Saga of Scandinavia. - Tore Ahlbäck (ed.) Western Esotericism, 254-80. Abo: Donner Institute.

\section{Wrede, Johan}

2005 Världen enligt Runeberg. En biografisk och idéhistorisk studie. Helsingfors: Svenska Litteratursällskapet i Finland. 
